\title{
OKUPANSI TANAH DALAM KAWASAN HUTAN YANG DIKELOLA PERUM PERHUTANI DIVRE JAWA TIMUR
}

\author{
Hanif Nurcahyo \\ Magister Kenotariatan Fakultas Hukum Universitas Brawijaya \\ Jl. MT. Haryono No. 169 Malang \\ hanifnurcahyo11@gmail.com
}

\begin{abstract}
Occupation by the Magersari community for settlements raises tenure or land disputes within forest areas. The settlement of land rights disputes by the Magersari community for settlement to Perum Perhutani East Java Regional Division is pursued by the Swap of Forest Area Exchanges. The purpose of this study is to find the legal implications of regulation on the mechanism of a land swap in the forest area and to find the constraining factor faced by Perum Perhutani East Java Regional Division in the process of land exchange within the forest area. The research approach is conducted by normative juridical. Subsequently classified and grouped the legal material and analyzed by qualitative juridical. The results of this study that the mechanism of exchange of state forest land for non-forestry interests many obstacles faced by the "magersari" community and Perum Perhutani.Hard difficult to find a replacement land adjacent to the forest. Birocracy permissions that make it difficult and takes a long time. Coordination between related institutions less resulting in overlapping authority.
\end{abstract}

Keywords: Occupancy, Exchange, Magersari, Enclave

\begin{abstract}
ABSTRAK
Okupasi yang dilakukan komunitas Magersari untuk pemukiman menimbulkan permasalahan tenurial atau tanah sengketa dalam kawasan hutan. Penyelesaian sengketa hak atas tanah kawasan hutan oleh komunitas Magersari untuk pemukiman kepada Perum Perhutani Divisi Regional Jawa Timur ditempuh dengan pola Tukar Menukar Kawasan Hutan. Tukar menukar kawasan hutan komunitas magersari menghilangkan enclave dalam rangka memudahkan Perum Perhutani Divisi Regional Jawa Timur mengelola kawasan hutan. Tujuan penelitian ini menemukan implikasi hukum peraturan tentang mekanisme tukar menukar tanah dalam kawasan hutan dan menemukan faktor penghambat yang dihadapi oleh Perum Perhutani Divisi Regional Jawa Timur dalam proses tukar-menukar tanah dalam kawasan hutan. Pendekatan penelitian dilakukan secara yuridis normatif. Selanjutnya diklasifikasikan dan dikelompokkan bahan hukum tersebut dan dianalisis secara yuridis kualitatif. Hasil penelitian ini bahwa mekanisme tukar menukar tanah hutan negara untuk kepentingan nonkehutanan banyak kendala yang dihadapi oleh komunitas magersari maupun Perum Perhutani.Sulitnya mencari lahan pengganti yang berdekatan dengan kawasan hutan. Birokrasi perijinan yang menyulitkan dan membutuhkan waktu yang lama. Koordinasi antar lembaga terkait yang kurang mengakibatkan tumpang tindih kewenangan.
\end{abstract}

Kata kunci: Okupansi, Magersari, Enclave. 
Hutan sebagai sumber daya alam memiliki arti dan nilai strategis. Nilai strategis hutan sebagai salah satu sumber daya alam yang dapat memberikan berbagai manfaat bagi kehidupan manusia. Manfaat ekologi, sosial dan manfaat ekonomi merupakan tiga pilar manfaat yang dapat diperoleh dari hutan. Nilai strategis hutan dapat pula didefinisikan dalam arti ekonomis, sebagai masukan sumber daya untuk meningkatkan pembangunan ekonomi dan sosial. Hal tersebut berarti bahwa hutan menyediakan basis sumber daya yang vital bagi perekonomian Indonesia.

Menurut data www.mongabay.co.id permasalahan tenurial dan konflik hutan dan lahan (2016, diakses pada 12 Januari 2016, 30) sudah sejak lama permasalahan kawasan hutan bukan terletak kepada sumberdaya yang ada di dalam hutan, tetapi lebih kepada masalah tenurial (tanah), tempat dimana hutan itu tumbuh dan berada. Kenyataannya yang disebut dengan kawasan hutan adalah wilayah tertentu (termasuk tanah) beserta dengan sumberdaya yang ada didalamnya.

Badan Usaha Milik Negara (BUMN) bidang Kehutanan yaitu Perum Perhutani diberi pelimpahan kewenangan untuk mengelola hutan Jawa dan Madura berdasarkan pada Penjelasan Pasal 21 Undang-Undang Nomor 41 Tahun 1999 tentang Kehutanan. Peraturan pelaksanaannya diteruskan pada Peraturan Pemerintah Nomor 72 Tahun 2010 tentang Perusahan Umum (Perum) Kehutanan Negara Pada Pasal 3 ayat (1). Pengelolaan hutan yang dilimpahkan Badan Usaha Milik Negara (yang selanjutnya disebut BUMN) kepada Perum Perhutani ini meliputi kegiatan-kegiatan yang termuat dalam Pasal 3 Ayat (3). Perusahaan Umum (Perum) Perhutani merupakan Perum yang didirikan pemerintah untuk melaksanakan usaha sebagai implementasi kewajiban pemerintah guna menyediakan barang dan jasa tertentu untuk memenuhi kebutuhan primer maupun sekunder bagi masyarakat.
Magersari sebagai komunitas penduduk dalam kawasan hutan sangat diandalkan oleh Perum Perhutani menjadi pemasok utama pengadaan tenaga kerja dalam kegiatan pengelolaan dan reforestasi hutan di Jawa, seperti penyadapan getah, penebangan kayu, pembibitan, penjarangan tanaman, penanaman bibit pohon, penyaradan, pengangkutan sampai penimbunan kayu. Sebagai imbalannya orang magersari selain diberi hak menggunakan tanah hutan untuk tempat tinggal juga diberikan hak secara terbatas untuk menggarap lahan-lahan hutan dengan sistem tumpangsari, mengambil kayu bakar, mencari rumput/ daun pakan ternak dan bahkan menggembalakan ternak di dalam kawasan hutan.

Di Jawa, khususnya di wilayah hukum Perum Perhutani Divisi Regional Jawa Timur, menurut Nurjaya $(2004,103)$, selain terdapat desa-desa di sekitar hutan juga dapat ditemukan komunitaskomunitas penduduk Magersari yang berada dalam kawasan hutan yang dikelola oleh Perum Perhutani Divisi Regional Jawa Timur. Secara geografis, letak komunitas-komunitas Magersari ini biasanya terpisah dari pemukiman penduduk desa di sekitar hutan. Namun kenyataannya sampai saat ini menurut administrasi pemerintahan desa, penduduk magersari menjadi bagian dari penduduk desa yang terdekat.

Kenyataan tugas Perum Perhutani Divisi Regional Jawa Timur dalam mengelola hutan negara bukanlah tugas yang ringan. Banyak tantangan dan hambatan yang dihadapi Perum Perhutani, khususnya dalam mengemban misi pelestarian hutan. Persoalannya sekarang yang dihadapi oleh Perum Perhutani Divisi Regional Jawa Timur adalah komunitas Magersari yang bermukim dalam tanah kawasan hutan negara bertahun-tahun, hingga turun temurun ke anak cucunya sampai saat ini, mengklaim tanah tersebut untuk diajukan permohonan hak atas tanah. Keadaan itulah pada akhirnya memunculkan suatu pemahaman di ka- 
langan masyarakat Magersari, bahkan di lingkup aparatur Pemerintah Daerah maupun DPRD, bahwa dengan berargumen "sudah menduduki dan menempati tanah tersebut selama sekian puluhan tahun lamanya" sebagai alas hak untuk memohon penerbitan sertifikat hak milik.

Sebagai contoh konflik tenurial pada komunitas Magersari yang berada di Desa Kebonagung, Kecamatan Mejayan, Kabupaten Madiun yang berada dalam kawasan hutan yang dikelola Perum Perhutani Kesatuan Pemangkuan Hutan (KPH) Madiun, Divisi Regional Jawa Timur. Kawasan hutan yang telah berubah fungsi menjadi kawasan pemukiman komunitas Magersari, sepanjang oleh Menteri Lingkungan Hidup dan Kehutanan belum diubah statusnya sebagai bukan kawasan hutan, maka wilayah tersebut tetap berstatus sebagai kawasan hutan. Setiap upaya pemberian hak atas tanah terhadap kawasan hutan yang telah diduduki (okupasi) sekian tahun lamanya bahkan turun temurun generasinya tetap diperlukan adanya mekanisme tukar menukar dan atau pelepasan kawasan hutan dari Kementerian Lingkungan Hidup dan Kehutanan.

Dengan demikian upaya untuk menyelesaikan persoalan tersebut harus ada sinergisitas yang baik dari semua stakeholder, baik dari pemohon (komunitas Magersari) itu sendiri, pemerintah daerah Provinsi, Kabupaten/Kota, pihak Perum Perhutani Divisi Regional, Kesatuan Pemangkuan Hutan, Kementerian Lingkungan Hidup dan Kehutanan, Kementerian Agraria dan Tata Ruang, dan pemangku kepentingan lainnya.

Beranjak dari uraian latar belakang di atas, maka penulis menyusun jurnal berdasarkan penelitian dengan rumusan masalahnya dalam klarifikasi mengenai permasalahan dimaksud adalah sebagai berikut: Bagaimanakah mekanisme tukar menukar tanah hutan negara menurut Peraturan Menteri Kehutanan Nomor: P.27/Menhut-II/2014 tentang Perubahan Kedua Atas Peraturan Menteri Kehutanan Nomor P.32/Menhut-II/2010 tentang
Tukar Menukar Kawasan Hutan. Apa kendala yang dihadapi Perum Perhutani Divisi Regional Jawa Timur dalam proses Tukar-menukar Kawasan Hutan Negara.Pendekatan penelitian dilakukan secara yuridis normatif, dalam arti menganalisis peraturan terkait mekanisme tukar menukar kawasan hutan.

\section{Mekanisme Tukar-Menukar}

Secara umum tukar-menukar diatur dalam Pasal 1541 Kitab Undang-Undang Hukum Perdata. Menurut Pasal 1541 Kitab Undang-Undang Hukum Perdata yang diartikan dengan tukar-menukar adalah "Persetujuan dengan mana kedua belah pihak mengikatnya dirinya untuk saling memberikan suatu barang secara timbal balik, sebagai gantinya suatu barang lain." Ada tiga unsur yang harus ada pada perjanjian tukar-menukar pada umumnya, yaitu: (1) adanya subjek hukum (kreditor dan debitor), (2) objek tukar-menukar, (3) objeknya sama besarnya, beratnya maupun luasnya.

Tukar-menukar kawasan hutan adalah perubahan kawasan hutan produksi tetap dan/ atau hutan produksi terbatas menjadi bukan kawasan hutan yang diimbangi dengan memasukkan lahan pengganti dari bukan kawasan hutan menjadi kawasan hutan begitu juga sebaliknya. Tukar-menukar kawasan hutan dilakukan apabila di wilayah yang bersangkutan tidak tersedia Hutan Produksi yang dapat dikonversi (HPK) dan hanya pada Hutan Produksi.

Selama ini mengenai perubahan peruntukan kawasan hutan, dalam bentuk tukar-menukar kawasan hutan diatur berdasarkan peraturan menteri kehutanan. Landasan yuridisnya yaitu Peraturan Menteri Kehutanan Republik Indonesia Nomor: P.32/Menhut-II/2010 tentang Tukar Menukar Kawasan Hutan. Selanjutnya berhubung dengan adanya perubahan ketentuan yang hanya beberapa pasal akhirnya terbit Peraturan Menteri 
Kehutanan Republik Indonesia Nomor: P.41/ Menhut-II/ 2012 tentang Perubahan Atas Peraturan Menteri Kehutanan Nomor P.32/Menhut-II/ 2010 tentang Tukar Menukar Kawasan Hutan.

Terakhir perubahan ketentuan ke dua yang hanya beberapa pasal terbit Peraturan Menteri Kehutanan Republik Indonesia Nomor: P.27/ Menhut-II/2014 tentang Perubahan Kedua Atas Peraturan Menteri Kehutanan Nomor P.32/MenhutII/2010 tentang Tukar Menukar Kawasan Hutan. Tukar menukar kawasan hutan tidak boleh mengurangi luas kawasan hutan tetap dan hanya dapat dilakukan dengan ketentuan:

1. Kawasan hutan yang dimohon berupa Hutan Produksi dan/ atau Hutan Produksi Tetap yang tidak dibebani izin penggunaan kawasan hutan, izin pemanfaatan hutan, persetujuan prinsip tukar menukar kawasan hutan, atau bukan merupakan Kawasan Hutan dengan Tujuan Khusus (KHDTK).

2. Tetap terjaminnya luas kawasan hutan paling sedikit 30\% (tiga puluh perseratus) dari luas Daerah Aliran Sungai, (DAS), pulau, dan/ atau provinsi dengan sebaran yang proporsional sehingga dapat mempertahankan daya dukung kawasan hutan tetap layak kelola.

3. Dilarang menebang pohon dan wajib mempertahankan keadaan vegetasi hutan pada kawasan perlindungan setempat pada areal dengan radius atau jarak sampai dengan 500 (lima ratus) meter dari tepi waduk atau danau; 200 (dua ratus) meter dari tepi mata air dan kiri kanan sungai di daerah rawa; 100 (seratus) meter dari kiri kanan tepi sungai; 50 (lima puluh) meter dari kiri kanan tepi anak sungai; 2 (dua) kali kedalaman jurang dari tepi jurang; dan 130 (seratus tiga puluh) kali selisih pasang tertinggi dan pasang terendah dari tepi pantai.

4. Tukar menukar kawasan hutan pantai berupa mangrove/ bakau, lahan pengganti harus lahanpantai berupa mangrove/bakau atau lahan pantai yang dapat dijadikan hutan mangrove/bakau.
5. Hal tidak tersedia lagi lahan pengganti berupa mangrove/ bakau atau lahan pantai yang dapat dijadikan hutan mangrove/ bakau, dapat diganti dengan lahan lain dengan persyaratan tambahan sesuai rekomendasi Tim Terpadu.

Perubahan peruntukan yang dilakukan melalui tukar-menukar kawasan hutan hanya dapat dilakukan pada hutan produksi tetap dan/ atau hutan produksi terbatas. Tukar-menukar kawasan hutan sebagaimana dimaksud, dilakukan untuk pembangunan di luar kegiatan kehutanan yang bersifat permanen, untuk menghilangkan enclave dalam rangka memudahkan pengelolaan kawasan hutan, serta untuk memperbaiki batas kawasan hutan.

Ketentuan dalam Pasal 4 ayat (2) dan (3) Peraturan Menteri Kehutanan Republik Indonesia Nomor: P.41/Menhut-II/2012 tentang Perubahan Atas Peraturan Menteri Kehutanan Nomor P.32/ Menhut-II/2010 tentang Tukar Menukar Kawasan Hutan. Kegiatan tukar menukar kawasan hutan dengan tujuan untuk pembangunan di luar kegiatan kehutanan yang bersifat permanen diklasifikasikan menjadi 3 (tiga) yaitu:

a. Untuk penempatan korban bencana alam,

b. Untuk kepentingan umum termasuk sarana penunjang yang meliputi (waduk dan bendungan, fasilitas pemakaman, fasilitas pendidikan, fasilitas keselamatan umum, rumah Sakit Umum dan Pusat Kesehatan Masyarakat, Kantor Pemerintahan, Permukiman/ Perumahan, Transmigrasi, Bangunan Industri, Pelabuhan, Bandar Udara, Stasiun Kereta Api, Terminal, Pasar Umum, Pengembangan/Pemekaran Wilayah, Pertanian Tanaman Pangan, Budidaya Pertanian, Perkebunan, Perikanan, Peternakan, Sarana Olahraga, Rest Area, Tugu Dan Pos Perbatasan Wilayah Administrasi Pemerintahan, Dan Stasiun Pengisian Bahan Bakar Umum), 
c. Untuk kepentingan umum yang dijabarkan diatas jika dilakukan oleh Pemerintah dan/ atau pemerintah daerah dikelompokkan sebagai kepentingan umum terbatas.

Berikutnya dalam penjelasan Pasal 5 Ayat (1) Huruf (a), tukar menukar kawasan hutan dalam hal luas kawasan hutan yang kurang dari 30\% (tiga puluh perseratus) dari luas daerah aliran sungai, pulau, dan/ atau provinsi dengan sebaran yang proporsional khususnya untuk menampung korban bencana alam dan kepentingan umum yang dilakukan oleh pemerintah dan/ atau pemerintah daerah yang dikelompokkan sebagai kepentingan umum terbatas sebagaimana dimaksud dalam Pasal 4 Ayat (3) dengan rasio paling sedikit 1:1.

Sedangkan untuk kepentingan umum, termasuk sarana penunjang di luar kepentingan umum terbatas sebagaimana dimaksud dalam Pasal 4 Ayat (2) Huruf (b) rasio paling sedikit 1:2. Selanjutnya penjelasan Pasal 5 Ayat (1) Huruf (b) tukar menukar kawasan hutan dalam hal luas kawasan hutan yang di atas 30\% (tiga puluh perseratus) dari luas daerah aliran sungai, pulau, dan/ atau provinsi dengan sebaran yang proporsional dengan rasio paling sedikit 1:1.

Persyaratan lahan pengganti dalam tukar menukar kawasan hutan yang harus dipenuhi adalah sebagai berikut:

1. Letak luas dan batas lahan penggantinya jelas;

2. Terletak dalam daerah aliran sungai, provinsi pulau yang sama;

3. Dapat dihutankan kembali dengan cara konvensional;

4. Tidak dalam sengketa dan bebas dari segala jenis pembebanan dan hak tanggungan; dan

5. Mendapat rekomendasi dari Gubernut dan Bupati/ Walikota.

Tukar menukar kawasan hutan dilakukan berdasarkan permohonan kepada Menteri yang diajukan oleh: Menteri atau Pejabat setingkat Menteri; Gubernur; Bupati/ Walikota; Pimpinan badan usaha; atau Ketua Yayasan.

Sejak diterimanya disposisi dari Menteri Lingkungan Hidup dan Kehutanan atas permohonan pemohon, Direktur Jenderal dalam jangka waktu 15 (lima belas) hari kerja melakukan penelaahan terhadap persyaratan administrasi dan teknis. Permohonan memenuhi syarat, Direktur Jenderal dalam jangka waktu 30 (tiga puluh) hari kerja melakukan penelaahan terhadap: Fungsi kawasan hutan berdasarkan peta penunjukkan kawasan hutan dan/ atau penetapan provinsi berikut perubahannya; Peruntukan kawasan hutan; Perizinan penggunaan kawasan hutan; Perizinan pemanfaatan hutan; Persyaratan lahan pengganti.

Jika hasil penelaahan tidak memenuhi syarat Direktur Jenderal atas nama Menteri dalam jangka waktu 7 (tujuh) hari kerja menerbitkan surat penolakan. Hal penelaahan telah memenuhi ketentuan, Menteri membentuk Tim Terpadu dan Sekretaris Jenderal atas nama Menteri membentuk Tim Tukar Menukar Kawasan Hutan. Tim Terpadu dan Tim Tukar Menukar Kawasan Hutan, sejak ditetapkannya Tim melakukan penelitian dan menyampaikan hasil pemelitian dan rekomendasi kepada Menteri, dengan tata cara dan mekanisme kerja serta pembiayaan sesuai ketentuan peraturan perundang-undangan.

Persetujuan prinsip tukar-menukar hutan memuat kewajiban bagi pemohon untuk:

1. Menyatakan clear and clean usulan lahan pengganti dengan ketentuan:

a. Terhadap tanah-tanah hak untuk usulan lahan pengganti, baik yang terdaftar maupun yang belum terdaftar, dilakukan pelepasan hak dengan memberikan ganti rugi;

b. Terhadap tanah-tanah hak untuk usulan lahan pengganti yang sudah terdaftar dilakukan pencoretan di buku tanah dan sertifikatnya dengan tujuan supaya tidak terjadi sertifikat ganda; dan 
c. Terhadap tanah-tanah hak usulan lahan pengganti yang belum terdaftar (Leter c/ Girik) dilakukan pencoretan di buku dan peta Desa, serta harus ada keterangan dari instansi pertanahan Kabupaten/ Kota yang menyatakan bahwa lahan pengganti tersebut belum terdaftar.

2. Membuat dan menyerahkan pernyataan berbentuk Akta Notaris berisi kesanggupan untuk:

a. Menanggung biaya tata batas terhadap kawasan hutan yang disetujui dan lahan pengganti yang diusulkan;

b. Menyediakan biaya dan melaksanakan reboisasi serta pemeliharaan tanaman terhadap lahan pengganti;

c. Menyerahkan garansi bank dari bank Pemerintah sebagai jaminan biaya pelaksanaan reboisasi dan pemeliharaannya sesuai dengan ketentuan peraturan perundangundangan kecuali pemohon Pemerintah dan/ atau pemerintah daerah;

d. Membayar nilai tegakan dan pungutan Provisi Sumber Daya Hutan (PSDH) atas hutan tanaman atau PSDH dan Dana Reboisasi (DR) atas hutan alam atas kawasan hutan yang dimohon sesuai ketentuan peraturan perundang-undangan.

3. Menyerahkan surat jaminan berbentuk Akta Notaris yang berisi bahwa apabila dikemudian hari usulan lahan pengganti terdapat cacat tersembunyi bersedia untuk mengganti lahan pengganti sesuai dengan peraturan ini;

4. Menandatangani Berita Acara Tukar Menukar (BATM) kawasan hutan yang memuat:

a. Serah terima dokumen usulan lahan pengganti untuk dijadikan kawasan hutan;

b. Kewajiban bagi pemohon untuk;

i. Menanggung biaya tata batas terhadap kawasan hutan yang dimohon dan lahan pengganti yang telah ditunjuk sebagai kawasan hutan dengan Keputusan Menteri; ii. Menyediakan biaya dan melaksanakan reboisasi serta pemeliharaan tanaman terhadap lahan pengganti yang telah ditunjuk sebagai kawasan hutan; dan

iii. Membayar nilai tegakan dan pungutan PSDH atas hutan tanaman atau PSDH dan DR atas hutan alam atas kawasan hutan yang dimohon berdasarkan hasil inventarisasi sesuai dengan ketentuan peraturan perundangundangan.

Berdasarkan Keputusan Menteri tentang penunjukan lahan pengganti sebagai kawasan hutan, pemegang persetujuan prinsip dalam jangka waktu paling lama 180 (seratus delapan puluh) hari kerja wajib melaksanakan tata batas kawasan hutan yang berasal dari lahan pengganti yang dilaksanakan oleh Panitia Tata Batas Kawasan Hutan sesuai dengan peraturan perundang-undangan.

Pelaksanaan tata batas secara teknis dapat dilakukan oleh konsultan yang mempunyai kompetensi dengan supervisi dari Kepala Balai. Kepala Balai menyampaikan hasil dari Panitia Tata batas Kawasan Hutan berupa Berita Acara Tata Batas (BATB) dan peta hasil tata batas kepada Direktur Jenderal.Terhadap kawasan hutan yang berasal dari lahan pengganti yang telah ditata batas dilakukan kegiatan reboisasi. Kegiatan reboisasi atas kawasan hutan dapat dilaksanakan oleh pemohon dan/ atau bekerjasama dengan badan usaha yang mempunyai kompetensi di bidang reboisasi.

Menurut data Badan Pusat Statistik Perum Perhutani Divisi Regional Jawa Timur (2009-2013), sebanyak 114 unit proses, dengan luas kawasan hutan yang dimohon seluas 5.077, 21 ha, tanah pengganti seluas $4.375,44$ ha. Tukar-menukar kawasan hutan di Provinsi Jawa Timur, dari sebanyak 114 unit yang dimohon, yang sudah selesai prosesnya baru sebanyak 16 unit. Sedangkan di 
luar pulau Jawa sebanyak 203 unit lokasi, sehingga total di seluruh Indonesia, lokasi yang diusulkan untuk tukar-menukar kawasan hutan mencapai 317 unit lokasi.

Proses pelaksanaan tukar-menukar kawasan hutan membutuhkan waktu yang cukup lama. Persoalan yang muncul dalam proses tukar-menukar kawasan ini, yaitu sulit atau lambatnya pemohon dalam merealisasi lahan atau areal pengganti yang disepakati dan disetujui. Sebagai contoh tukar-menukar kawasan hutan dalam wilayah pengelolaan Perum Perhutani Divisi Regional Jawa Timur yaitu masyarakat magersari di Pujon Selatan dengan Surat Bupati Malang Nomor 590/1514/ 429.011/1997 tanggal 31 Agustus 1997 rekomendasi tukar menukar Kawasan Hutan seluas $\pm 5,20 \mathrm{Ha}$ yang dimohon oleh masyarakat Dusun Tulungrejo, Desa Pujon Selatan dengan usulan calon lahan pengganti seluas $\pm 7,7$ ha yang terletak didesa Bandungrejo, Kecamatan Bantur, Kabupaten Malang.

Permohonan Kepala Dinas Kesehatan Provinsi Jawa Timur terhadap kawasan hutan untuk Rumah Sakit (RS) Paru Dungus Madiun dalam rangka memperoleh legalitas penyelenggaraan Rumah Sakit sesuai dengan ketentuan peraturan perundang-undangan dari Kementerian Kesehatan Republik Indonesia bahwa Rumah Sakit harus berdiri diatas tanah milik sendiri sehingga penggunaan kawasan hutan untuk Rumah Sakit Paru Dungus Madiun perlu diproses lebih lanjut yaitu melalui mekanisme tukar menukar Kawasan Hutan (TMKH).

Surat Direksi Perum Perhutani Nomor 168/ 044.3/PusrenSDH/Dir, tanggal 11 Agustus 2015 perihal pemeriksaan/ peninjauan lapangan terhadap permohonan tukar menukar kawasan hutan untuk Rumah Sakit Paru Dungus Madiun. Luas kawasan hutan yang dimohon untuk Rumah Sakit Paru Dungus Madiun adalah kawasan hutan dengan fungsi hutan produksi seluas $\pm 8,47 \mathrm{Ha}$. Terletak di Petak 293a pada kawasan hutan dengan status fungsi hutan produksi yang dikelola oleh Perum
Perhutani Divisi Regional Jawa Timur, dengan Rencana Pengaturan Kelestarian Hutan (RPKH) Kelas Perusahaan (KP) Jati, Bagian Hutan (BH) Caruban, Kesatuan Pemangkuan Hutan (KPH) Madiun. Wilayah administrasi di jalan Raya Wungu Dungus, Kecamatan Wungu, Kabupaten Madiun.

\section{Kendala yang dihadapi Perum Perhutani Divisi Regional Jawa Timur dalam proses Tukar-Menukar Kawasan Hutan Negara}

Upaya yang dilakukan Perum Perhutani Divisi Regional Jawa Timur sangat-sangat maksimal yaitu berkoordinasi dengan para pihak terhadap proses prosedural aturan yang harus ditempuh. Akan tetapi upaya yang dilakukan Perum Perhutani Divisi Regional Jawa Timur tersebut belum juga menunjukkan efektif yang signifikan dan Perum Perhutani Divisi Regional Jawa Timur menyadari betul hal tersebut.

Proses kegiatan tukar menukar kawasan hutan membutuhkan waktu yang sangat lama, tidak hanya berbulan-bulan bahkan bertahuntahun. Berikut beberapa faktor dan kendala penghambat yang dihadapi oleh Perum Perhutani Divisi Regional Jawa Timur dalam menangani kegiatan proses tukar menukar kawasan hutan di wilayah kerjanya:

\section{a. Sulitnya Mencari Lahan Pengganti yang Berdekatan Dengan Kawasan Hutan}

Kendala yang dihadapi oleh Perum Perhutani di wilayah kerja Unit II Divisi Regional Jawa Timur dalam menangani kegiatan proses tukar menukar kawasan hutan, adalah lahan pengganti yang cukup sulit. Karena lahan tersebut nantinya sebagai pengganti kawasan hutan yang di mohon, otomatis lahan pengganti tersebut nantinya dikukuhkan kembali sebagai kawasan hutan oleh Kementerian Lingkungan Hidup dan Kehutanan.

Paling tidak lahan pengganti tersebut mengandung unsur-unsur dan kriteria yang sesuai dengan 
ketentuan Pasal 6 Peraturan Menteri Kehutanan Republik Indonesia Nomor: P.41/Menhut-II/ 2012 tentang Perubahan Atas Peraturan Menteri Kehutanan Nomor P.32/Menhut-II/2010 tentang Tukar Menukar Kawasan Hutan yaitu (1) Letak, luas dan batas lahan penggantinya jelas; (2) terletak dalam daerah aliran sungai, provinsi atau pulau yang sama; (3) dapat dihutankan kembali dengan cara konvensional; (4) tidak dalam sengketa dan bebas dari segala jenis pembebanan dan hak tanggungan; (5) rekomendasi dari Gubernur dan Bupati/ Walikota.

Lahan pengganti biasanya kurang sesuai untuk peruntukannya sebagai kawasan hutan, terdapat masyarakat yang tidak tahu menahu dan tidak mengerti apa yang akan ditetapkan pemerintah baik tingkat daerah Provinsi maupun Kabupaten/ Kota.

\section{b. Birokrasi Perijinan yang Menyulitkan dan Membutuhkan Waktu Yang Sangat Lama}

Kendala yang bersifat administratif dengan kurangnya koordinasi yang baik merupakan penghambat juga yang memakan waktu yang cukup lama dalam hal perizinan di lintas sektor dan antar instansi yang berwenang terkait proses tukar menukar kawasan hutan. Kendala ini terjadi karena adanya proses birokrasi yang terjadi antara Pemerintah Kabupaten Malang dengan Perum Perhutani Divisi Regional Jawa Timur. Birokrasi yang dilakukan di Pemerintah Daerah yang lambat, yang mendorong proses tukar menukar kawasan hutan yang diajukan masyarakat magersari Pujon Selatan Kabupaten Malang memakan waktu yang lama.

Proses tukar menukar kawasan hutan yang ada di wilayah hukum Perum Perhutani Divisi Regional Jawa Timur, khususnya Komunitas Magersari Pujon Selatan telah dilakukan dengan proses sebagai berikut:

Pertama, Bupati Malang atas nama masyarakat Desa Pujon Kidul, menyampaikan surat ke- pada Perum Perhutani Divisi Regional Jawa Timur melalui surat Nomor: 590/1514/429.011/1997 tertanggal 31 Agustus 1997 untuk mengajukan permohonan tukar menukar Kawasan Hutan dengan luas $\pm 5,0721 \mathrm{Ha}$, terletak di Petak 93b, 94a dan 99c, RPH Pujon Selatan, BKPH Pujon, KPH Malang dan secara administrasi pemerintahan termasuk dalam wilayah Desa Pujon Kidul, Kecamatan Pujon, Kabupaten Malang, Provinsi Jawa Timur.

Kedua, menteri Lingkungan Hidup dan Kehutanan memberikan Surat Persetujuan Nomor 494/Menhutbun-VII/1998 tanggal 13 April 1998 seluas 5, 20 Ha yang telah menjadi pemukiman penduduk, secara administrasi kehutanan yang berlokasi di petak 93b, 94a, dan 99c, RPH Pujon Selatan, BKPH Pujon, KPH Malang Perum Perhutani Divisi Regional Jawa Timur dan secara administrasi pemerintahan termasuk Desa Pujon Kidul, Kecamatan Pujon, Kabupaten Malang, Provinsi Jawa Timur dengan proses tukar-menukar rasio 1:1 (penyelesaian okupasi) dengan tanah pengganti seluas 5,2000 Ha di RPH Sumbermanjing Kulon, BKPH Sengguruh, $\mathrm{KPH}$ Malang dengan wilayah administrasi pemerintahan Desa Bandungrejo, Kecamatan Bantur, Kabupaten Malang.

Penetapan rasio ini sesuai dengan Pasal 5 Ayat (1) Huruf (a) Angka 1 Peraturan Menteri Kehutanan Republik Indonesia Nomor: P.41/ Menhut-II/2012 tentang Perubahan Atas Peraturan Menteri Kehutanan Nomor P.32/Menhut-II/2010 tentang Tukar Menukar Kawasan Hutan. Berarti persyaratan tukar-menukar telah memenuhi syarat. Artinya, secara hukum perdata khususnya menurut perjanjian tukar-menukar yang merupakan timbal balik dengan sifat yang sama dan jumlah yang sama. Dengan demikian proses ini secara hukum telah memenuhi persyaratan.

Ketiga, Proses hukum administrasi yakni hukum kehutanan, proses ini dilanjutkan dengan Perum Perhutani Divisi Regional Jawa Timur selaku pengelolaan hutan di wilayah Jawa Timur dan Madura memiliki kewajiban. Hal ini berarti bahwa 
Perum Perhutani dengan surat Nomor 914/DIR tertanggal 10 Juni 1998 perihal persetujuan dan tindak lanjut terhadap proses tukar menukar kawasan hutan di Desa Pujon, Kidul Kecamatan Pujon, Kabupaten Malang, Provinsi Jawa Timur mengeluarkan pertimbangan terhadap calon tanah pengganti kawasan hutan (tukar-menukar) di Desa Bandungrejo, Kecamatan Bantur, Kabupaten Malang.

Keempat, penandatanganan Berita Acara Tukar Menukar (BATM) kawasan hutan Nomor 02/BATM/Kamas/II/2000 tanggal 21 Februari 2000 antara Kepala Perum Perhutani Divisi Regional Jawa Timur dengan Sdr. Suprapto selaku mewakili atas nama Masyarakat Magersari Pujon Selatan, Kecamatan Pujon, Kabupaten Malang, dengan kesepakatan tukar menukar kawasan hutan sebagai berikut:

a. Kawasan hutan yang dimohon seluas 5,0721 Ha (berdasarkan hasil pengukuran) terletak di Petak 93b, 94a, dan 99c, RPH Pujon Selatan, BKPH Pujon, KPH Malang Perum Perhutani Divisi Regional Jawa Timur dan secara administrasi pemerintahan termasuk Desa Pujon Kidul, Kecamatan Pujon, Kabupaten Malang, Provinsi Jawa Timur; dan

b. Lahan pengganti seluas 5,1076 Ha (berdasarkan hasil pengukuran) terletak di Desa Bandungrejo, Kecamatan Bantur, Kabupaten Malang berhimpitan dengan kawasan hutan Petak 99d, RPH Sumbermanjing Kulon, BKPH Sengguruh, KPH Malang.

Kelima, Penandatanganan Berita Acara Monitoring dan Evaluasi dalam Rangka Tukar Menukar Kawasan Hutan untuk Permukiman Penduduk Atas Nama Masyarakat Magersari Pujon Selatan Di Kabupaten Malang, Provinsi Jawa Timur,7 September 2015.

Keenam, Surat Bupati Malang atas nama masyarakat Magersari Desa Pujon Kidul, menyampaikan surat dengan perihal Penataan Batas ka- wasan Hutan kepada Kepala Balai Pemantapan Kawasan Hutan Wilayah XI Jawa-Madura dengan Nomor 590/6129/421.014/2015.

Proses mulai dari pengajuan tukar menukar Kawasan Hutan hingga penandatanganan Berita Acara Monitoring dan Evaluasi dalam Rangka Tukar Menukar Kawasan Hutan memakan waktu selama 18 (delapan belas) tahun, yang selanjutnya direspon Bupati Malang dengan menyurati Kepala Balai Pemantapan Kawasan Hutan Wilayah XI Jawa-Madura perihal Penataan Batas kawasan Hutan. Ini terlalu konsumtif waktu, artinya pekerjaan birokratif untuk menangani masalah tukar menukar tidak efisien dan efektif. Hal ini, memang sifat administrasi yang terlalu panjang jalan dari Pemerintah Daerah ke Kementerian Lingkungan Hidup dan Kehutanan.

Setelah itu terjadi pula kendala yang bersifat yuridis. Kendala seperti ini yang harusnya diselesaikan bersamaan dengan penyelesaian administrasi, karena menyangkut status dan kepastian hak atas tanah yang di okupasi oleh masyarakat magersari Pujon Selatan. Penyelesaian masalah yuridis sebagaimana secara clear and clean di dalam Berita Acara Tukar Menukar Kawasan Hutan antara Kepala Perum Perhutani Divisi Regional Jawa Timur dengan Sdr. Suprapto selaku mewakili atas nama Masyarakat Magersari Pujon Selatan, Kecamatan Pujon, Kabupaten Malang, terkait dengan penyelesaian hak dan kewajiban dari kedua belah pihak.

\section{c. Koordinasi Antar Lembaga Terkait yang Kurang yang Mengakibatkan Tumpang Tindih Kewenangan}

Sektoralisasi dari penguasaan Sumber Daya Alam (SDA) tersebut serta implikasinya terhadap tanah negara dapat diuraikan sebagai berikut. Pertama, secara historis, sektoralisasi tersebut terjadi pada periode ke dua kebijakan pertanahan yang ditandai dengan munculnya berbagai peraturan perundang- undangan sektoral yang tidak 
mengacu pada UUPA, yang terbit karena di picu oleh masalah penggalangan dana besar pada awal periode pembangunan ekonomi.

Saat ini nama dari otoritas yang mengelola sumber daya alam tersebut adalah tanah oleh Kementerian Agraria dan Tata Ruang; hutan oleh Kementerian Kehutanan dan Lingkungan Hidup, air oleh Kementerian Negara Pekerjaan Umum (PU), wilayah pesisir oleh Kementerian Kelautan dan Perikanan, mineral dan batubara serta minyak dan gas bumi oleh Kementerian Energi dan Sumber Daya Mineral (ESDM). Masing-masing otoritas tersebut menerima mandat sebagai pengelola "hak menguasai negara" atas sektor-sektor tersebut. Hal ini, yang perlu diperhatikan dan mendorong pembentukan kebijakan terpadu dalam penguasaan tanah dan kawasan hutan dan koordinasi kewenangan antara sektor yang terkait dengan urusan penguasaan tanah dan kawasan tanah.

Penguasaan hutan oleh negara bukan merupakan pemilikan, tetapi sebagaimana ditegaskan dalam Pasal 4 Ayat (2) Undang-Undang Kehutanan, bahwa Negara memberi wewenang kepada Pemerintah untuk mengatur dan mengurus segala sesuatu yang berkaitan dengan hutan, kawasan hutan dan hasil hutan, menetapkan kawasan hutan dan atau mengubah status kawasan hutan mengatur dan menetapkan hubungan antara orang dengan hutan atau kawasan hutan dan hasil hutan, serta mengatur perbuatan hukum mengenai kehutanan. Selanjutnya pemerintah mempunyai wewenang untuk memberikan izin dan hak kepada pihak lain untuk melakukan kegiatan di bidang kehutanan. Namun demikian untuk hal tertentu yang sangat penting berskala dan berdampak luas serta bernilai strategis, pemerintah harus memperhatikan aspirasi rakyat melalui persetujuan Dewan Perwakilan Rakyat.

Ketidaktuntasan tersebut secara normatif mengakibatkan terjadinya tumpang tindih kewenangan dalam kebijakan perubahan peruntukan dan fungsi kawasan hutan dengan pendaftaran hak atas tanah. Akhirnya menimbulkan tidak harmonis antara kebijakan maupun hukum yang berlaku dan secara empiris menimbulkan konflik vertical karena masing-masing pengaturan dan pengurusan sumber daya agraria dilaksanakan oleh instansi atau departemen pemerintah yang berbeda. Konflik vertikal tersebut khususnya dengan UndangUndang Kehutanan terlihat adanya dualisme penguasaan dan pengurusan tanah. Tanah-tanah dalam kawasan hutan menjadi kewenangan otoritas kehutanan dan tanah-tanah diluar kawasan hutan menjadi kewenangan otoritas pertanahan.

Akibatnya Pemerintah sulit untuk melakukan pengelolaan, perlindungan, perencaanaan, pengawasan, penegakan hukum dan rehabilitasi kawasan hutan karena sektor, wilayah dan daerah menjalankan aturan kebijakan dan kepentingannya masing-masing. Melalui harmonisasi hukum akan terbentuk sistem hukum yang mengakomodasi tuntutan akan kepastian hukum dan terwujudnya keadilan. Begitu pula dalam hal penegakan hukum, harmonisasi hukum akan dapat dihindari adanya tumpang tindih bagi badan peradilan yang melakukan kekuasaan kehakiman, dengan badan pemerintah yang diberi wewenang melakukan fungsi pemerintahan menurut peraturan perundangundangan.

Produk hukumnya seharusnya berbentuk Peraturan Bersama maupun Surat Keputusan Bersama (SKB) antara Kementerian Lingkungan Hidup dan Kehutanan dengan Kementerian Agraria dan Tata Ruang, dengan maksud tukar menukar kawasan hutan dalam keputusan bersama tersebut yaitu pengubahan status kawasan hutan dari tanah yang dikuasai oleh negara menjadi hak atas tanah dengan hak milik kepada komunitas masyarakat magersari yang berada dalam kawasan hutan yang dikelola oleh Perum Perhutani Divisi Regional Jawa Timur untuk keperluan relokasi pemukiman penduduk dalam rangka menghilangkan enclave. 
Perumus kebijakan dari berbagai instansi sektoral seyogyanya mempelajari data, fakta dan hal yang bersifat teknis serta berpijak pada ketentuan yang berlaku, sehingga dapat sejalan dengan rambu-ranbu yang telah ditetapkan. Misalnya persoalan perubahan status hak atas tanah yang menjadi kewenangan Kementerian Agraria dan Tata Ruang (BPN) dan perubahan peruntukan fungsi kawasan hutan yang menjadi kewenangan Kementerian Lingkungn Hidup danKehutanan, seharusnya antara kedua lembaga ini dapat berkoordinasi dengan baik, karena bisa saja akan ada titik singgung antara kedua objek tersebut.

Demikian juga hal yang terkait dengan persoalan sertifikasi, penataan ruang, dan sebagainya. Koordinasi dimaksud, agar adanya saling sinergi yang baik dan tidak berjalan sendiri. Kepentingan bersama perlu dilakukan langkah secara proporsional untuk menciptakan kesinambungan. Koordinasi dilakukan dalam mewujudkan sinkronisasi dan harmonisasi berbagai pihak atau antar sektor, antar wilayah/ daerah, sehingga semua kepentingan dapat terakomodasi dengan baik.

\section{Penutup}

Berdasarkan hasil analisis atas data-data yang peneliti peroleh dalam penelitian tentang tukar menukar tanah dalam kawasan hutan yang dikelola Perum Perhutani Divre Jawa Timur, maka dapat diambil kesimpulan bahwa Kegiatan mekanisme tukar menukar kawasan hutan yang merujuk pada Peraturan Menteri Kehutanan Nomor: P.27/Menhut-II/2014 tentang Perubahan Kedua Atas Peraturan Menteri Kehutanan Nomor P.32/ Menhut-II/2010 tentang Tukar Menukar Kawasan Hutan tidak melibatkan Kementerian Keuangan dalam menginvetarisasi kekayaan /aset negara. Hal ini bertentangan dengan Undang- Undang Nomor 1 Tahun 2004 tentang Perbendaharaan Negara.
Kebijakan Tukar Menukar Kawasan Hutan di Desa Pujon Kidul, Kecamatan Pujon, Kabupaten Malang, Provinsi Jawa Timur ini mengalami hambatan dikarenakan ada beberapa factor antara lain perubahan regulasi Peraturan Menteri Kehutanan Republik Indonesia Nomor: P.41/Menhut-II/2012 tentang Perubahan Atas Peraturan Menteri Kehutanan Nomor P.32/Menhut-II/2010 tentang Tukar Menukar Kawasan Hutan. Selanjutnya Peraturan Menteri Kehutanan Republik Indonesia Nomor: P.27/Menhut-II/2014 tentang Perubahan Kedua Atas Peraturan Menteri Kehutanan Nomor P.32/Menhut-II/2010 tentang Tukar Menukar Kawasan Hutan. Prosedur pengajuan permohonan tukar menukar kawasan hutan diproses dari awal kembali, dikarenakan adanya perubahan peraturan Menteri Kehutanan dan ketentuan yang baru sehingga harus menyesuaikan.

\section{DAFTAR PUSTAKA}

\section{Buku}

Harsono, Boedi, 2008, Hukum Agraria Indonesia: Sejarah Pembentukan Undang-Undang Pokok Agraria, Isi dan Pelaksanaannya, Djambatan, Cetakan keduabelas (edisi revisi), Jakarta.

HS, Salim, 2003, Dasar-Dasar Hukum Kehutanan, Sinar Grafika, Jakarta.

Iskandar, 2015, Hukum Kehutanan "Prinsip Hukum Pelestarian Fungsi Lingkungan Hidup Dalam Kebijakan Pengelolaan Kawasan Hutan Berkelanjutan", Mandar Maju, Bandung.

Nurjaya, I Nyoman., 2004, MAGERSARI: Dinamika Komunitas Petani-Pekerja Hutan Dalam Perspektif Antropologi Hukum, UM Press, Malang.

Safitri, Myrna A. dkk., 2011, Menuju Kepastian dan Keadilan Tenurial, Edisi Revisi, Jakarta.

Supriadi, 2007, Hukum Agraria, Sinar Grafika, Jakarta.

Supriyadi, Bambang Eko., 2013, Hukum Agraria Kehutanan, Raja Grafindo Persada, Jakarta. 


\section{Jurnal Cakrawala Hukum}

Vol.7, No.2 Desember 2016: 183-194

\section{Peraturan Perundang-Undangan}

Undang-Undang Nomor: 5 Tahun 1960 tentang Peraturan Dasar Pokok-Pokok Agraria.

Undang-Undang Nomor: 41 Tahun 1999 tentang Kehutanan.

Peraturan Pemerintah Republik Indonesia Nomor: 72 Tahun 2010 tentang Perusahaan Umum (Perum) Kehutanan Negara.

Peraturan Menteri Kehutanan Republik Indonesia Nomor: P.32/Menhut-II/2010 tentang Tukar Menukar Kawasan Hutan.

Peraturan Menteri Kehutanan Republik Indonesia Nomor: P.41/Menhut-II/2012 tentang Perubahan
Atas Peraturan Menteri Kehutanan Nomor P.32/ Menhut-II/2010 tentang Tukar Menukar Kawasan Hutan.

Peraturan Menteri Kehutanan Republik Indonesia Nomor: P.27/Menhut-II/2014 tentang Perubahan Kedua Atas Peraturan Menteri Kehutanan Nomor P.32/ Menhut-II/2010 tentang Tukar Menukar Kawasan Hutan.

\section{Internet}

Anonim, www.mongabay.co.id, 2016, diakses pada 12 Januari 2016. 